\title{
Serving Underserved Populations: Implications from a Model of Successful Services for Deaf and Hard of Hearing Children in Public Libraries
}

Bobbie Bushman, University of North Texas, USA

\begin{abstract}
There is a current movement in public libraries towards increasingly inclusive programming. This research presents the findings from a study of library programs for deaf and hard of hearing $(\mathrm{D} / \mathrm{HoH})$ children. Using the grounded theory approach, it highlights the successful practices of U.S. public libraries working with $\mathrm{D} / \mathrm{HoH}$ children. Nearly five hundred mediumand large-sized libraries were contacted; fifteen librarians volunteered to be interviewed and eleven were ultimately interviewed. Interviews were analyzed using open and axial coding. Based on the empirical data, the Model of Successful Library Services for D/HoH Children was developed. The model explains the services, early literacy instruction, and programs offered by public librarians to $\mathrm{D} / \mathrm{HoH}$ children and identifies four stages of service delivery which highlight: (1) staff attitudes; (2) impetus for providing services for $\mathrm{D} / \mathrm{HoH}$ patrons; (3) accommodations through inclusive programming, American Sign Language (ASL) programming, or visual phonics; and (4) outcomes of this work in terms of educating both hearing and $\mathrm{D} / \mathrm{HoH}$ individuals and of building a sense of community. This paper focuses on the Model of Successful Library Services for D/HoH Children to determine whether its four stages of service may also be applied to other marginalized populations in order to facilitate successful library programming.
\end{abstract}

Keywords: diversity; inclusion; marginalized populations; successful library programming; underserved populations

Publication Type: research article

\section{Introduction}

$\mathrm{n}$ the U.S., public libraries are increasingly providing programming for diverse populations, including such groups as deaf and hard of hearing $(\mathrm{D} / \mathrm{HoH})$ children. Most public children's librarians are trained to use the early literacy program produced by the American Library Association (ALA) titled "Every Child Ready to Read" (ECRR) (http://everychildreadytoread.org). While some public libraries have created their own early literacy programs, the vast majority of librarians are trained in ECRR. As of 2011, ECRR reports that over 6,000 U.S. libraries have purchased their toolkit (ALA, n.d.).

This grounded theory study was inspired by the ECRR training I received as a practicing children's librarian. After becoming ECRR-trained, I began to wonder how the program might apply to diverse populations like $\mathrm{D} / \mathrm{HoH}$ children. ECRR identifies phonological awareness as a required pre-literacy skill, but does not instruct librarians how $\mathrm{D} / \mathrm{HoH}$ children might learn that skill. ECRR emphasizes the importance of songs and rhyming in story times, but does not suggest ways in which $\mathrm{D} / \mathrm{HoH}$ children can learn songs or rhymes. Questions about how to 
implement ECRR with $\mathrm{D} / \mathrm{HoH}$ children became the driving force for this research, which stands to address a gap in the library literature about how public libraries serve $\mathrm{D} / \mathrm{HoH}$ children. It is a study which seems long overdue.

Public libraries have the opportunity to play a vital role in providing early literacy programming and education to $\mathrm{D} / \mathrm{HoH}$ children and their families. This intervention by librarians could be instrumental in increasing the reading level for $\mathrm{D} / \mathrm{HoH}$ adults in the U.S.. Additionally, having a child diagnosed with $\mathrm{D} / \mathrm{HoH}$ can be isolating for families because support is often not available until the child enters school. Not only can libraries offer leisure reading materials for $\mathrm{D} / \mathrm{HoH}$ children, such as American Sign Language (ASL) books, graphic novels, and DVDs with closed captioning; they can also offer a physical space in which to hold ASL classes, support groups, and other events for the $\mathrm{D} / \mathrm{HoH}$ community. In order to continue with this critical role, public librarians must be knowledgeable about effective ways of engaging $\mathrm{D} / \mathrm{HoH}$ individuals as well as members of other marginalized populations.

This research began by gathering information about the types of library services provided for $\mathrm{D} / \mathrm{HoH}$ children, the kinds of early literacy programs utilized by public librarians with this group of patrons, the types of modifications made to serve $\mathrm{D} / \mathrm{HoH}$ children, and the impetus for providing these services and programs. The data was collected and analyzed to produce the Model of Successful Library Services for D/HoH Children; there is no previous equivalent model.

This paper also addresses how the Model of Successful Libraries Services for D/HoH Children might apply to other underserved populations, extending the findings of this research beyond the population of $\mathrm{D} / \mathrm{HoH}$ children. When libraries offer programming to an underserved population, they might experience similar obstacles, utilize the same techniques, and derive comparable lessons to those noted in the work with $\mathrm{D} / \mathrm{HoH}$ children.

\section{Literature Review}

Although the literature about serving diverse populations may be growing, information about library services for $\mathrm{D} / \mathrm{HoH}$ children is scarce. Over the past sixteen years, reports of providing library services for $\mathrm{D} / \mathrm{HoH}$ children include accounts of ASL story times, ASL classes, and $\mathrm{D} / \mathrm{HoH}$-focused collection development. Some libraries train their staff in ASL or hire staff who are already fluent in ASL. The literature outlining such public libraries services for $\mathrm{D} / \mathrm{HoH}$ individuals, as well as some of the tools that have become available to these libraries, is summarized below.

The Safety Harbor Public Library in Pinellas County, Florida, served their D/HoH population by teaching ASL to children and adults. They reported that program attendees were family members of individuals with $\mathrm{D} / \mathrm{HoH}$ or people wanting to learn a new language (Rodriguez \& Reed, 2003). The Safety Harbor Public Library's family story times offered a place for both $\mathrm{D} / \mathrm{HoH}$ and hearing parents and children to interact (Rodriguez \& Reed, 2003). The Safety Harbor Public Library also arranged homework assistance and language modeling to hearing children of $\mathrm{D} / \mathrm{HoH}$ adults (Rodriguez \& Reed, 2003) and featured a deaf literacy center, which hosted many activities, including a nationwide library-based adult literacy program for $\mathrm{D} / \mathrm{HoH}$ adults and their families (Pinellas Public Library Cooperative, 2016). Hands and Johnson (2012) examined several other libraries which facilitated ASL story times for $\mathrm{D} / \mathrm{HoH}$ and hearing families, taught early literacy workshops for parents of $\mathrm{D} / \mathrm{HoH}$ children, and provided outreach programs for $\mathrm{D} / \mathrm{HoH}$ family members.

The International Journal of Information, Diversity, \& Inclusion, 2(3), 2018

ISSN 2574-3430, publish.lib.umd.edu/IJIDI/ 
Many American libraries continue to add ASL videos to their collections. In addition to building a collection of closed-captioned movies, Nail (2008) reported that Canadian libraries purchased a series of DVDs called ASL Tales. ASL Tales offered children's books with accompanying DVDs, each of which featured stories told in ASL and provided web-linked learning tools. This DVD series can serve as a solid introduction to ASL and become an asset to any library collection. The Argo Library/School Media Center in Colorado reported carrying a large number of books with $\mathrm{D} / \mathrm{HoH}$ characters. Their video collection contained $\mathrm{ASL}$ instruction, information on $\mathrm{D} / \mathrm{HoH}$ culture, and stories told in ASL (Arnold, 2002).

The Springfield Massachusetts City Library responded to a $\mathrm{D} / \mathrm{HoH}$ child attending their programs by purchasing ASL books. The outreach librarian also began working with a local school for $\mathrm{D} / \mathrm{HoH}$ children. The library paid her to take ASL courses at the $\mathrm{D} / \mathrm{HoH}$ school. The librarian was then able to read stories in ASL and make connections with D/HoH children (Lajoie, 2003). Some libraries also offered disability training to help staff to better serve their patrons. The Cleveland Heights-University Heights Public Library in Ohio offered specialized training with $\mathrm{D} / \mathrm{HoH}$ patrons in mind. They hired staff with basic ASL knowledge and paid them to advance their ASL education. The library paid for interpreters and $\mathrm{D} / \mathrm{HoH}$ materials, as many libraries also do. The Ohio library also provided outreach to $\mathrm{D} / \mathrm{HoH}$ patrons and computer classes for $\mathrm{D} / \mathrm{HoH}$ individuals (Noland, 2003).

Christine Wixtrom of Alexandria, Virginia, founded ASL Access, a nonprofit, volunteer-run organization that supplies public libraries with ASL resources. ASL Access created a collection of videos featuring ASL instruction, ASL story times, and D/HoH culture information (MacMillan, 2003). This resource is still being sold to libraries to date.

Graphic novels are a library resource especially beneficial for D/HoH children because "faced with challenges in reading comprehension, students who are $\mathrm{D} / \mathrm{HoH}$ can benefit greatly from the use of words and pictures together to convey information" (White, 2011, p. 20). Researchers speculate that $\mathrm{D} / \mathrm{HoH}$ readers are more easily able to comprehend graphic novels due to the visual nature of ASL (White, 2011, p. 21). Graphic novels have grown in popularity; by adding this type of material to their collections, libraries are simultaneously becoming more inclusive of $\mathrm{D} / \mathrm{HoH}$ children.

Librarian Harley Hamilton created My Sign Link, a free online ASL dictionary which translates words typed into the dictionary prompt with a video of the sign for that word. Hamilton created the 17,000-word dictionary with only a $\$ 500$ budget (McCaffrey, 2004b). Today, there are many of these free online dictionaries available, including ASL Pro, Life Print, and Hand Speak. Hamilton also approached Weston Woods, a creator of children's films with captioning, and asked them to create signed retellings of popular children's novels on film (McCaffrey, 2004a).

Universal design is a set of principles based on research that lends a framework for using technology to maximize learning for all (Blue \& Pace, 2011). One successful example of utilizing universal design, called the Child's Place, was implemented by the Brooklyn Public Library in New York in 1987 and is still in existence today. The library offers drop-in programs in English, Spanish, and ASL. Story times and other programs were multi-sensory and featured books and a variety of activities in ASL (Banks, 2004).

Another ongoing program which continues to offer $\mathrm{D} / \mathrm{HoH}$ services is that at the Monroe County Library System in New York. With $\$ 99,150$ in grant money from the Library Services and

The International Journal of Information, Diversity, \& Inclusion, 2(3), 2018 ISSN 2574-3430, publish.lib.umd.edu/IJIDI/ 
Technologies Act to offer several programs for children and youth with diverse needs, the library trained staff and began programming in ASL (Wemett, 2007).

\section{Methodology}

The incentive for this grounded theory research was derived from my experience as a practicing children's librarian attempting to apply ECRR to $\mathrm{D} / \mathrm{HoH}$ children with whom I interacted in the public library. I became aware of the lack of both knowledge and existing models for providing library services to diverse populations. The purpose of grounded theory research is to provide an explanation or a model where none is present (Bryant \& Charmaz, 2007). The grounded theory research I conducted also relied on the naturalistic setting (such as observing how a librarian facilitates $\mathrm{D} / \mathrm{HoH}$ programming in a public library) and self-generated questions typical in grounded theory. The real-life experience of the subjects helps to create research "about real people or objects to which they can relate" (Bryant \& Charmaz, 2007, p. 114). This inherent relevance was necessary to build a future model for practicing librarians to use when serving $\mathrm{D} / \mathrm{HoH}$ children and other underserved populations.

The goal of this study was to learn how librarians deliver programming to $\mathrm{D} / \mathrm{HoH}$ children, which modifications they make to accommodate $\mathrm{D} / \mathrm{HoH}$ children, and how they decide which services to offer to $\mathrm{D} / \mathrm{HoH}$ children and their families. Of particular interest were the ways in which librarians modified story times and other early literacy programming to make them more inclusive.

Creswell's (2009) qualitative research procedures were followed as well as those for grounded theory from Bryant and Charmaz (2007). The mode of data collection was semi-structured interviews conducted in 2014. The goal was to conduct interviews until saturation was reached, as evidenced by coding comparisons. Repeated information was obtained, even with this small sample size (eleven interviews, as described below). Each interview took approximately thirty minutes. Interview questions were designed to begin a dialog with the librarian in order to learn about starting and maintaining a program for $\mathrm{D} / \mathrm{HoH}$ children. Typical of qualitative research, questions were open-ended, conversational, and subject to modification. Interviews were concluded by inviting each librarian to share anything else they would like related to their work with $\mathrm{D} / \mathrm{HoH}$ children. As expected, librarians with the most experience had more insight to share and would often offer additional information related to serving $\mathrm{D} / \mathrm{HoH}$ children.

Open-ended interviews and the qualitative approach allowed participating librarians to tell their stories about delivering library services to the $\mathrm{D} / \mathrm{HoH}$ community. Utilizing a list of semistructured questions (Appendix B), the interviews were nonetheless flexible; the questions were modified according to each interviewee's experience and appropriate follow up and clarifying questions were posed. The interview questions were designed after conducting similar research on the broader topic of library services to children with diverse needs (Adkins \& Bushman, 2015). Some questions were also generated based on my personal experience with $\mathrm{ECRR}, \mathrm{D} / \mathrm{HoH}$ individuals, and the review of literature.

Interview questions were pre-tested with a librarian at a $\mathrm{D} / \mathrm{HoH}$ school and an early literacy expert for $\mathrm{D} / \mathrm{HoH}$ children. Both pre-test interviewees were recruited through snowball sampling via an initial contact made with a principal at a school for the $\mathrm{D} / \mathrm{HoH}$. Preliminary interviews were conducted, transcribed, and coded to determine whether the questions were appropriate to the topic and the audience. These interviews were not included in the final

The International Journal of Information, Diversity, \& Inclusion, 2(3), 2018 ISSN 2574-3430, publish.lib.umd.edu/IJIDI/ 
data. The pre-test interviews consisted of about seven initial questions with follow-up questions as needed. Each preliminary interview resulted in approximately five pages of transcribed text and included the topics of program planning, staff attitude, implementation, successes, failures, and obstacles. These pre-test interviews helped to identify gaps in my knowledge as a researcher and to refine the interview questions.

According to Bryant and Charmaz (2007), theoretical triangulation is a mode of verification used while engaging in data gathering and analysis, and it is used to create a checks and balances system. Theoretical triangulation uses multiple perceptions to clarify meaning. In this research, interviews and library websites served as the basis for triangulation. The interviews were conducted on the phone, recorded, and transcribed.

Grounded theory emphasizes the use of open, axial, and selective coding (Creswell, 2008) when using the systematic design. During the coding process, data was distilled and sorted as described by Charmaz (2006), in order to make comparisons and recognize overarching themes. After transcribing interviews, open coding was initiated by identifying in vivo codes, which "capture" a "participant's words as representative of a broader concept in the data" (Birks \& Mills, 2011, p. 93). Significant phrases (in vivo codes) were extracted from the interviews and pasted into a coding table that placed them alongside an initially assigned code (open code). The in vivo codes were extracted based on their ability to address this study's research questions. An early coding example can be found in Appendix D.

In grounded theory research, open and axial coding are intertwined in such a way that any distinction between them is artificial and used for explanatory purposes only (Corbin \& Strauss, 2008). During open coding, labels or headings were assigned to the text to categorize it. In some cases, more than one heading was used per in vivo code. These headings became more specific and succinct as coding progressed. Axial codes are formed by comparing the events found in one code with the next (Charmaz, 2006). In grounded theory, comparing codes allows categories to emerge and connections to be made among the data (Charmaz, 2006). By comparing portions of similarly coded interviews, the overarching themes of this grounded theory begin to develop as similarities among the interviews became apparent. To reveal these axial codes and themes, open coded data was matched. Memos and notes served to indicate commonalities between participants' responses to broaden or narrow codes. It was through this process that the Model of Successful Library Services for D/HoH Children began to emerge.

There are two primary ways of validating a coding scheme (or methodology) in qualitative analysis. The first method of validation is to compare the scheme against the raw data, with the researcher completing the high-level analysis; the second method is to tell the story to participants and obtain feedback via member checking (Corbin \& Strauss, 2008). For this research, both methods were utilized. Throughout the coding process, participants' stories were continually compared against one another and checked against codes and supporting documents. This assisted with the accurate preservation of the participants' experiences.

Transcribed interviews and supporting documents were stored on a password-protected server and ultimately deleted. No identifying information was stored. Any names of people, towns, libraries, nearby agencies, or other identifying information was omitted in transcription.

In order to verify the model for this research, three interview participants (who indicated they would like to know the outcome of the research), were contacted for follow-up interviews. (Interestingly, these three participants also had the most experience creating $\mathrm{D} / \mathrm{HoH}$ 
programming.) They were emailed with a reminder about the study and a copy of the Model of Successful Library Services for D/HoH Children. Then they were asked to indicate whether this model reflected their experiences and, if not, whether they could add anything that was missing from the model. Only one participant responded, but she reported that she thought the model was "excellent" in explaining the process of providing services to $\mathrm{D} / \mathrm{HoH}$ children. Additional verification was sought by cross checking interviews and codes against one another when looking for themes in the data to ensure that a consistent story emerged about how $\mathrm{D} / \mathrm{HoH}$ programming was conducted in libraries.

\section{Participants}

Library information was obtained from the data file for the 2010 Public Libraries Survey from the Institute of Museum and Library Services (IMLS) website, which contained 9,308 records (IMLS, 2010). Only libraries with service populations greater than 100,000 people across the U.S. were selected, and the list was narrowed down to 540 medium- and large-sized public libraries. Email addresses for children's librarians were obtained from library websites for 490 librarians. A recruitment script (Appendix A) and survey instrument (Appendix B) were sent via email to those 490 librarians for the purpose of determining participation interest and experience in working with $\mathrm{D} / \mathrm{HoH}$ children (Appendix $\mathrm{C}$ ).

Of the 490 librarians who were sent surveys, fifteen librarians indicated in the survey that they would be willing to be interviewed, however, only ten of those fifteen librarians were reached using the contact information provided. Others were unreachable, but one more interviewee was added to the sample through snowballing. As a result, a total of eleven interviews were conducted after the participants were given informed consent forms.

Of the eleven librarians interviewed, all but one were female. Six of the interview participants were children's librarians. Interviews were also conducted with management-level librarians who were not the library staff interacting with D/HoH children. Those who were not children's librarians held the following job titles: Youth Services Coordinator, Deaf Literacy Coordinator, Early Literacy Specialist, Youth Services Manager, Community Engagement Coordinator, and Adult Services Coordinator. The librarians and the corresponding libraries in which they work are identified numerically (1-11) in the discussion below.

\section{The Model}

Using the research questions, a grounded theory model for providing successful library services for $\mathrm{D} / \mathrm{HoH}$ children was developed. The Model of Successful Library Services for D/HoH Children explains how librarians are serving $\mathrm{D} / \mathrm{HoH}$ children in U.S. public libraries in the absence of existing systems to serve $\mathrm{D} / \mathrm{HoH}$ children. This paper discusses how the model (Fig. 1) can be applied more broadly, beyond serving $\mathrm{D} / \mathrm{HoH}$ children, to provide more inclusive programming for all patrons. The version of the model included in this paper represents a refinement and revision of the previously published iterations of the same model, including revised terminology and additional stages. 


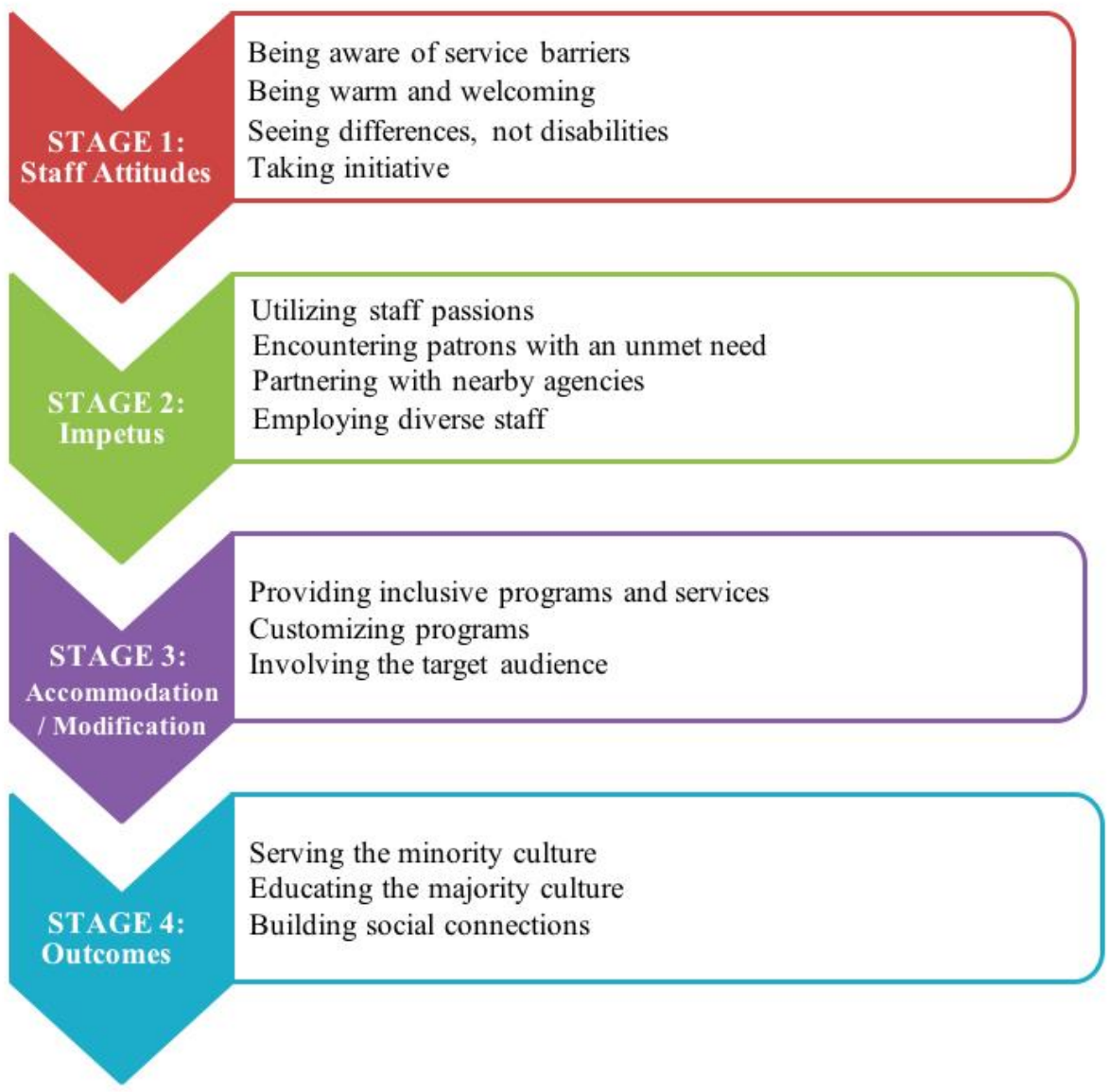

Figure 1. Model of Successful Library Services for D/HoH Children

\section{Results and Discussion}

The Model of Successful Library Services for D/HoH Children outlines which services, early literacy instruction, staff training, and programs public libraries offer to children who are $\mathrm{D} / \mathrm{HoH}$ and outlines four stages of providing those services. The first stage of the model highlights the fact that successful programming begins with staff whose attitudes are warm and welcoming, who take initiative, and who do not see those who are $\mathrm{D} / \mathrm{HoH}$ as having a disability. The second stage looks at the impetus for providing services and identifies positive examples, including encountering a $\mathrm{D} / \mathrm{HoH}$ patron in the library, knowing someone with a disability personally, and encountering a nearby agency that serves $\mathrm{D} / \mathrm{HoH}$ individuals. The third stage outlines successful accommodations libraries make for $\mathrm{D} / \mathrm{HoH}$ individuals, which include providing inclusive programming, ASL programming, or ECRR modifications such as substituting visual phonics for phonological awareness. The fourth and final stage of this model describes successful outcomes for these services: educating both hearing and $\mathrm{D} / \mathrm{HoH}$ individuals 
and creating a sense of community. Though the Model of Successful Library Services for D/HoH Children is focused on public library services for children who are $\mathrm{D} / \mathrm{HoH}$, larger implications may be drawn by applying the model to other marginalized populations.

\section{Stage 1. Staff Attitudes}

\section{Being Aware of Service Barriers}

Interviews of eleven librarians across the U.S. who were offering services, programming, or accommodations to $\mathrm{D} / \mathrm{HoH}$ patrons revealed some common staff attitudes. Particularly important among these attitudes was having an awareness of barriers to service and creating a warm and welcoming environment in spite of those barriers. Librarians often want to know where to begin when considering new programming, especially for underserved groups. Being aware of policies and other issues that may impede library service to certain populations is a good first step. For example, a librarian may ask: What are the requirements to obtain a library card at my library? Does asking for certain documents exclude a group of potential patrons? If so, are there contingent policies for those patrons? Should a library reevaluate that policy to make it more inclusive? Or is there flexibility within that policy to serve diverse patrons? Similarly, a librarian may ask: What are the physical barriers present at my library? Most libraries today strive to be compliant with the Americans with Disabilities Act (ADA), with such accommodations as elevator access and designated parking, but how user-friendly are a library's computers, stacks, and reference desks? Would the height of a reference or circulation desk be comfortable for all users? Is there a computer station for patrons who are visually impaired? Is there a computer station with wheelchair access? Are the stacks wide enough to accommodate all users? Can all patrons retrieve books from the tallest shelves? These are just some of the questions librarians can begin to ask themselves to be more aware of the barriers to library and information service. These barriers may include policies, physical spaces, language difficulties, and other issues that will impede the provision of exceptional library service to some populations. Awareness is the first step to finding ways to welcome diverse patrons.

Some libraries have populations that they deem problematic, although, as Wong (2009) points out, referring to a group of people as "problem patrons" is certainly discriminatory. Still, some groups receive this label in public libraries, including homeless populations, mentally ill patrons, and teenagers. With some effort, these "problematic" patrons can become an asset to the library. This was demonstrated by Librarian 7 who described how $\mathrm{D} / \mathrm{HoH}$ patrons were taking items without checking them out and causing disturbances that required police intervention. Librarian 7 helped to change the library policies and to hold information sessions to explain library rules. Check-out periods were explained, as were the use of auditory alarms to signal that an item was not properly checked out. Some $\mathrm{D} / \mathrm{HoH}$ patrons were surprised to learn that an alarm was going off when they walked out the door with an unchecked out item. This example illustrates why it is important to address cultural differences and expectations. Librarians must remember that even patrons who seem problematic often have a legitimate information need that has been unaddressed (Wong, 2009).

\section{Being Warm and Welcoming}

Although this study is focused on the $\mathrm{D} / \mathrm{HoH}$ community, the need for library staff to project a warm and welcoming attitude can be applied to service for other groups of library patrons as well. Librarians should be warm and welcoming to all patrons, which can be expressed in 
different ways. For example, at Library 4, librarians are "trying to say that we're warm and welcoming and we want you [patrons] here." Librarian 3 concurred, noting that their programs are "always open" to anyone. Similarly, Librarian 8 emphasized that "all of [their] children's programs" welcome "children of all different developmental needs," an assertion which was echoed by Librarians 1, 5, and 11. Librarian 4 also noted that they "make sure [to] have an interpreter available to make the $[\mathrm{D} / \mathrm{HoH}]$ community feel comfortable and to let the parent know that they are welcome in our story times." Another librarian shared that they "had a woman ... . who knew enough sign language to be able to assist a customer. The customer was really put at ease" (Librarian 2). Librarian 4 was emphatic that their offerings are "more of an inclusive story time rather than specifically singling out because we want these children-all children-to be able to interact with each other and learn from this experience."

\section{Seeing Differences, not Disabilities}

Participants also consistently reported not viewing individuals with hearing impairments as disabled. This sentiment was expressed by Librarian 6 who mentioned that "differences are celebrated" and "[deafness is] communication, which isn't a disability." Librarian 9 echoed, "we just don't really make a big deal about it. We just help every child to the best of our abilities."

Deafness is often considered a culture rather than a disability. In fact, it is common to discuss the $\mathrm{D} / \mathrm{HoH}$ community in the same way one might discuss any other community that shares a language and culture. Librarian 7 acknowledged that "it's a whole culture and a whole language," while Librarian 6 also described how her library perceives the Deaf as a group that speaks another language, adding that they "offer story times in Somali, Spanish, etc.; so having an ASL story time was just a natural offshoot."

\section{Taking Initiative}

Staff initiative was a vital component in the successful provision of $\mathrm{D} / \mathrm{HoH}$ programming. Librarians reported feeling personally responsible for ensuring that programming and accommodations were available for $\mathrm{D} / \mathrm{HoH}$ children. Many times, librarians put accommodations in place without consulting supervisors or other staff members. As one librarian describes: "I just took a chance and said, 'Yes. I commit to doing this.' And then I went to my manager. If I'd gone to my manager first, I don't know that it would've happened." Librarian 10 shared that one program became available only because "there was a staff member who really took the reins." Librarian 7 stated that

It's really hard to reach $[\mathrm{D} / \mathrm{HoH}]$ children. That's why I go into the school. These parents are overwhelmed between doctors' appointments and the fact that you just found out that this child is $\mathrm{D} / \mathrm{HoH}$ and you have speech therapy and 500 other things. The last thing you think of is bringing your $\mathrm{D} / \mathrm{HoH}$ child to the library to story time. So, whatever program we do we bring it there.

Librarian 2 discussed how she collects programming feedback and subsequently makes programming changes. All of these accounts reflect the importance of staff initiative in providing successful $\mathrm{D} / \mathrm{HoH}$ programming. 


\section{Stage 2. Impetus}

\section{Utilizing Staff Passions}

Librarians who had served $\mathrm{D} / \mathrm{HoH}$ children had several reasons for offering the service or program that they provided. Knowing someone with a disability, encountering a $\mathrm{D} / \mathrm{HoH}$ patron, or having an agency for $\mathrm{D} / \mathrm{HoH}$ people close to their library were the most common reasons for initiating $\mathrm{D} / \mathrm{HoH}$ library services. All librarians have interests and passions outside of the library. They may volunteer, and they may have personal connections to marginalized communities. Library managers can fully utilize these connections by finding out more about the staff they employ and, by so doing, expand a wealth of resources at their fingertips.

In this study, many librarians reported feeling accountable to the $\mathrm{D} / \mathrm{HoH}$ population. If all librarians felt that way about underserved groups, diverse library services would significantly improve. The sense of responsibility and accountability creates a favorable situation for both librarians and patrons they serve. Librarians are already experts in niche areas of traditional librarianship (such as reference or reader's advisory), but they can expand their areas of expertise to include social justice and outreach to underserved groups. Consider the patron impact of a librarian gaining expertise in services to the homeless, developing a Spanish language collection, or becoming knowledgeable about national and local mental health resources. For instance, at the University of Michigan library, staff strengths are used to increase responsiveness to community interests in creating programming (Vander Broek \& Rodgers, 2015). Similarly, in this study librarians explained their passion for and commitment to serving the $\mathrm{D} / \mathrm{HoH}$ community.

Librarian 9 described how the children's librarian "had a passion for deaf children and their education," while she herself felt passionate about $\mathrm{D} / \mathrm{HoH}$ programming because she had a "profoundly deaf nephew." Librarian 4 commented that they had librarians who also worked at a school with developmentally disabled children. Because of that experience, Librarian 4 said, "we have staff members who feel this is a personal thing for them."

\section{Encountering Patrons with an Unmet Need}

Another common reason for initiating $\mathrm{D} / \mathrm{HoH}$ library services was encountering a $\mathrm{D} / \mathrm{HoH}$ person at the library. Sometimes the $\mathrm{D} / \mathrm{HoH}$ individual came to a library program, and other times, the librarian met that person while providing reference or other informational services. Many librarians described anticipating or reacting to the needs of $\mathrm{D} / \mathrm{HoH}$ individuals as an impetus for their programming. All libraries have underserved populations where similar responsiveness would likely illicit similar successful programming.

At Library 7, they developed programming because $\mathrm{D} / \mathrm{HoH}$ people who used the library did not understand the rules, as was reflected in the incident described earlier, in which patrons took out books without checking them out. As Librarian 7 commented,

[A patron] tells you all the libraries are a free of charge place. Well, there was no explanation that they have to be returned or when. All they heard was free books, videos, and you can check out twenty at a time-and they started checking out all this stuff and never returning it.

As a solution she proposed a compromise whereby the library would let patrons "check out one 
item at a time and they can keep it for as long as they can. Because one big problem that some of them were having was like, 'Well, the group home didn't bring us here for two weeks!'”

Librarian 5 shared how in their library, staff members responded to complaints from $\mathrm{D} / \mathrm{HoH}$ patrons that some of the library's videos were mislabeled. For example, they would be labeled as closed captioned, and the patron would take them home only to discover that this was not the case. To rectify this problem, the library purchased a DVD player to keep at the front desk where patrons could test the DVDs for closed captioning before taking them home.

Librarian 5 also reported that they began programming because, they "had a child who was deaf who came in and wanted to participate." Librarian 6 added, "if we have a child who's deaf and needs support in a program, we hire interpreters." Similarly, Librarian 8 said, "if we see a child that is not responding to what we're doing, we modify." Librarian 2 recounted how a deaf family made their needs known and the library responded, and Librarian 8 mentioned that their programming started with a deaf and blind baby who started to visit the library. Library 11 had patrons requesting ASL interpreters. All of these libraries began serving $\mathrm{D} / \mathrm{HoH}$ patrons at their library simply because they encountered a $\mathrm{D} / \mathrm{HoH}$ patron with an unmet need.

\section{Partnering with Nearby Agencies}

Librarians who worked with $\mathrm{D} / \mathrm{HoH}$ children often reported being close to a school for the $\mathrm{D} / \mathrm{HoH}$, an employer for the $\mathrm{D} / \mathrm{HoH}$, or another community agency for the $\mathrm{D} / \mathrm{HoH}$. Librarians utilized these contacts to attract patrons, to recruit volunteers, and to promote programming. In this study, such partnerships were often an impetus for providing D/HoH programming.

As mentioned, libraries frequently utilized volunteers in the development of $\mathrm{D} / \mathrm{HoH}$ programming. Librarian 7 described how she sought out these volunteers:

I went to the college and talked to the program director [of deaf studies] and said, "I understand your students need contact hours. They need to be out there with the deaf. I have the deaf and I have nobody with them."

The same librarian reported getting different volunteers from a local company that employs the $\mathrm{D} / \mathrm{HoH}$ and pays its employees to volunteer for up to twenty hours a year. Similarly, Library 9 began a program that relied exclusively on volunteers for the first three years.

It stands to reason, therefore, that when working with underserved populations, librarians can initiate programs by cooperating with nearby agencies. Not only can librarians go to the agencies for outreach, but they can also set up special times for that agency to bring in their clients. If programs hosted by the library are of interest to their partnering agency, the agency will likely help to promote the library event, thus increasing the library reach in the respective community.

Oftentimes partnerships arise from a connection that library staff has with non-profit agencies. However, as Massis (2013) points out, libraries can also successfully partner with retail and other for-profit organizations in ways that are beneficial for both the library and the company. Librarian 9 recalled that "over the years, we've worked with various agencies from our hearing, speech and deafness center to deaf theater groups, student groups, agencies who support deaf services, and community programs" to offer more

The International Journal of Information, Diversity, \& Inclusion, 2(3), 2018

ISSN 2574-3430, publish.lib.umd.edu/IJIDI/ 
diverse programming.

\section{Employing Diverse Staff}

One way whereby librarians can improve their engagement of diverse populations, including members of the $\mathrm{D} / \mathrm{HoH}$ community, is by employing diverse staff. Sadly, the current composition of the library profession does not reflect the diversity of library patrons (Jaeger, Bertot, \& Subramaniam, 2013). ALA reports that most librarians are white women without disability (ALA Office for Research \& Statistics, 2017). The lack of diversity in representation is unfortunate; many sources emphasize that patrons seek assistance from a "neighbor who looks just like them" (Hastings, 2015, p. 134). Currently the ALA diversity report notes that diversity has actually decreased in public libraries in the past 20 years, so there is much room for improvement in this area (Davis \& Hall, 2007). Kumbier and Starkey (2016) point out that to be inclusive in one area is not enough. Librarians must "recruit, educate, hire, and support library workers with disabilities" as well as other minorities (p. 482).

In this study, there were several examples of how hiring diverse staff led to improved $\mathrm{D} / \mathrm{HoH}$ services and programs. Librarian 8 thought that more $\mathrm{D} / \mathrm{HoH}$ children visited the library because they employed an HoH children's librarian, whose "presence reassured parents that we consider it normal and it's not a big deal." Similarly, Librarian 10 noticed that D/HoH children were visiting more often in order to talk to their staff member who had hearing loss and knew ASL. Librarians 5 and 9 reported that their libraries had staff members who knew ASL. For Libraries 5, 8, 9, and 10, having staff who were $\mathrm{D} / \mathrm{HoH}$ or spoke ASL was a common impetus for offering successful $\mathrm{D} / \mathrm{HoH}$ programming.

In addition to hiring more diverse librarians, libraries can reassure community members that diversity is central to library operations. If a library employs a staff member who speaks another language or has a cultural identity or awareness of a minority group, this skill or knowledge should be demonstrated to the public. One practical way is to advertise to patrons that librarians speak ASL, Spanish, Russian, or other languages, by creating name tags or signs letting patrons know that their language is spoken in the library. Similarly, signs or social media posts can help patrons get to know their librarians and their areas of expertise.

\section{Stage 3: Accommodation/Modification}

\section{Providing Inclusive Programs and Services}

Most interviewed librarians reported efforts to provide inclusive programming. Librarian 1 revealed that she gave away a free book as the prize for the completion of their summer reading program, as many public libraries do, however, at her library, the prize book choices were more inclusive. Participants could choose to receive a printed book, a Braille book, or an audiobook. Library 2 brought in an ASL translator for the children's performer they hired. In Library 6, a projector was used for hands-free storytelling to help the storyteller communicate in ASL.

Librarians 2, 4, 5, 8, and 11 each commented that their programming was inclusive of and welcoming to anyone. Being aware of the populations that libraries serve and then thinking about those populations' needs are important first steps. The libraries represented in this study, however, not only offered multilingual story times in ASL, but also often featured a $\mathrm{D} / \mathrm{HoH}$ person or signer as the primary storyteller or program facilitator. This actively engages 
and empowers community members and sends a message that the target audience's language is not an afterthought but a focus and an essential element of the program.

\section{Customizing Programs}

Librarians who were providing successful story times customized programming for $\mathrm{D} / \mathrm{HoH}$ children, making accommodations specifically for $\mathrm{D} / \mathrm{HoH}$ individuals such as restructuring story times, changing policies, and developing $\mathrm{D} / \mathrm{HoH}$ collections and hiring interpreters. Several librarians described writing or exchanging notes with their $\mathrm{D} / \mathrm{HoH}$ patrons to facilitate interactions. One librarian reported keeping a dry-erase board behind their front desk as a practical communication tool for staff unfamiliar with ASL. A library that served patrons who are both deaf and blind provided each of these patrons with an interpreter who could translate using tactile signs during programming. Several libraries used the help of ASL-speaking volunteers, many of whom were recruited through partnerships with colleges that offered ASL classes. Library 8 included $\mathrm{D} / \mathrm{HoH}$ children in their story times but reported that many of these children were able to hear normally with hearing aids or cochlear implants. To accommodate these $\mathrm{HoH}$ children, and their $\mathrm{HoH}$ aging population as well, they received a grant to get a $\mathrm{t}$ coil system installed under the carpet of their auditorium. This allowed them to host events in which the speaker wore a special microphone that was automatically picked up by anyone wearing an assistive hearing device. This was not only helpful for patrons, but was also beneficial for staff meetings, which included a hearing-impaired children's librarian.

At one library, a deaf boy came to a year-long program in which children read to service dogs. The boy had verbal outbursts which, of course, he could not hear. As a result, the service dogs became afraid and uncooperative. To accommodate this boy, the librarian spoke to his mother, and they made a plan to ask the service dog provider to offer their most tolerant dog to the boy. This dog then went into a room alone with the boy (away from the other children and service dogs) and the boy successfully read to him. This modification allowed this child to remain in the program. Librarian 8 shared that they made sure to learn tactile ASL in order to work with a blind and deaf child attending her story time.

Library 6 bought an easel so that their deaf storyteller could easily hold the book and turn the pages during story time. Library 9 offered a customized story time activity in which participants made a "who book" which featured "the sign for 'who' on the front of the book and the sign [...] for me, mother, father, grandmother" inside. Library 7 held regular ASL classes at all their library branches which were open to all ages to help friends and family members of $\mathrm{D} / \mathrm{HoH}$ individuals to learn ASL. Librarian 4 commented that they made "a concerted effort to try to bring in special speakers to address those concerns and questions" that were specific to the $\mathrm{D} / \mathrm{HoH}$ community. Librarian 9 said that they purchased the movie Deaf Jam to show at a library program which featured an interpreter and a deaf poetry slam. Library 6 offered a program that specifically addressed domestic violence in the $\mathrm{D} / \mathrm{HoH}$ community. Library 7 held a jewelry crafters group for $\mathrm{D} / \mathrm{HoH}$ women each week. The women made necklaces and listed them for sale online. They then sent the proceeds to $\mathrm{D} / \mathrm{HoH}$ women in South America. Library 7 hosted a D/HoH culture event at their library once a month. To do this, they created celebrations based on the recognized national holidays and events. For example, their library marks Black Deaf History Month and Deaf Hispanic Heritage Month. They also facilitated book discussions for $\mathrm{D} / \mathrm{HoH}$ individuals, which were led by a deaf proficient reader who had read the book and differed from standard book discussions by not assuming that attending individuals had read the book. Librarian 6 described having a book group in ASL that focused on $\mathrm{D} / \mathrm{HoH}$ adults.

The International Journal of Information, Diversity, \& Inclusion, 2(3), 2018

ISSN 2574-3430, publish.lib.umd.edu/IJIDI/ 
When providing customized programming, librarians must consider issues specific to the target audience. Librarian 7 described the process of deciding whether or not her library needed to offer customized computer classes and story times for $\mathrm{D} / \mathrm{HoH}$ individuals as follows:

We had computer classes and we would try to bring the deaf to the computer classes. Because they're looking down and they have to look at the interpreter and then type, the teacher was already speaking and going on to the next thing. The hearing people are now finding Yahoo and the deaf person doesn't even know that we have to look for Yahoo yet. So, we decided to have our own classes. The same thing with the storytelling.

Librarians 4 and 10 emphasized that their libraries had been serving the $\mathrm{D} / \mathrm{HoH}$ community for a long time and indicated that their use of a TTY device, a device which allows $\mathrm{D} / \mathrm{HoH}$ individuals to use a landline telephone for assisted listening, became a significant link to the $\mathrm{D} / \mathrm{HoH}$ community and first brought $\mathrm{D} / \mathrm{HoH}$ individuals into their libraries. While not every library has a large community of $\mathrm{D} / \mathrm{HoH}$ people residing in their catchment area, every library always has a group of patrons with unique needs who are interested in having programs customized to fit those needs.

\section{Involving the Target Audience}

Offering programs for a particular group makes it necessary to include members of that group in planning, delivering, and evaluating the program. As Kumbier and Starkey (2016) explain, the popular slogan used to advocate for people with disabilities, "Nothing about us, without us" means that we must make room for people with disabilities in leadership roles, not just as members. In this study, there were many programs that were planned with the help of people from within the target audience.

Library 9 utilizes a deaf signer to conduct story times. Library 6 reports having a deaf storyteller at story times. These story times feature the $\mathrm{D} / \mathrm{HoH}$ person as the primary performer and have the hearing person serve as the interpreter. At Library 9, $\mathrm{D} / \mathrm{HoH}$ individuals in the community advocated for $\mathrm{D} / \mathrm{HoH}$ services to the library, which included having a $\mathrm{D} / \mathrm{HoH}$ person write a grant so the library could pay for the requested services. Similarly, Librarian 6 reports, "the deaf community has been very integral in making sure that the library stays connected and engaged so it's definitely been a wonderful partnership."

Responsiveness to a community's needs and including the target audience in programming will increase a library program's attendance. When librarians ask underserved groups to assist with planning and facilitating the library program, those individuals will tell other members of the underserved group about the library's services and programs. A library can quickly build a reputation for serving underserved groups this way, as described by Librarian 7: "everyone knows about [our library services for the $\mathrm{D} / \mathrm{HoH}$ ]. People move into town and right away they're here [at the library]."

\section{Stage 4: Outcomes}

\section{Serving the Minority Culture}

In addition to other challenges, $\mathrm{D} / \mathrm{HoH}$ people have limited access to sources of information and a limited number of these sources compared to hearing individuals. One obvious challenge 
is that $\mathrm{D} / \mathrm{HoH}$ people require close captioning and assistive technologies to access electronic and audio-visual information, including news and current events. Libraries are, at times, the only institutions providing reading and language instruction for $\mathrm{D} / \mathrm{HoH}$ children before they enter school.

Education was a major theme of interviews in this study, which has implications beyond the $\mathrm{D} / \mathrm{HoH}$ community. Library programming for $\mathrm{D} / \mathrm{HoH}$ children attracted hearing children with hearing parents, hearing children with $\mathrm{D} / \mathrm{HoH}$ parents, and $\mathrm{D} / \mathrm{HoH}$ children with hearing parents. Hearing parents shared that library programs taught them about $\mathrm{D} / \mathrm{HoH}$ culture and taught their children about diversity. Librarians reported that children learned to respect differences as a result of observing a $\mathrm{D} / \mathrm{HoH}$ person communicate in ASL. Librarians also stressed that library programming for $\mathrm{D} / \mathrm{HoH}$ children and adults helped $\mathrm{D} / \mathrm{HoH}$ individuals to learn early literacy, improve ASL, and master information literacy.

Librarian 7 explained why meeting the needs of the $\mathrm{D} / \mathrm{HoH}$ community was so important:

I think that this is where deaf people need to be. We have everything that they don't have: information. Nobody tells them what's happening around them. And here, we subscribe to the deaf magazines and we're always showing them videos.

Librarian 9 recalled her experiences meeting the needs of $\mathrm{D} / \mathrm{HoH}$ children, saying, "the results are quite astounding when $[\mathrm{D} / \mathrm{HoH}]$ children get that one on one help." She added, "this is one of the places where they get regular exposure to ASL and an opportunity to use it and to see it [used]." Librarian 9 further described positive programming outcomes for D/HoH children, stating that their "programming increased the reading comprehension of deaf children who attended by $43 \%$."

\section{Educating the Majority Culture}

Librarians commented that $\mathrm{D} / \mathrm{HoH}$ individuals were not the only people who attended their programs. Positive outcomes were also reported for the members of the hearing community who took part in library offerings. Hearing parents shared with librarians that they had learned much about $\mathrm{D} / \mathrm{HoH}$ culture and that the $\mathrm{D} / \mathrm{HoH}$ program served as a teaching opportunity about the diversity of life experiences. As Librarian 9 noted, "the hearing people that come get exposed to deaf culture. It's just pretty amazing." Librarian 6 commented, "we explain to the children that although it could be a male voice or a female voice that you hear, we want you to focus on the individual who is signing because they're communicating." This librarian also observed that there is "comfort that comes [for hearing children] with understanding deafness."

Several libraries in this study offered ASL classes to hearing individuals. Sometimes the attendees knew someone who was $\mathrm{D} / \mathrm{HoH}$ and sometimes they did not. Librarian 9 described teaching hearing parents ASL so that they could communicate with their deaf child and remarked that "the results are quite astounding-when parents learn to sign" in order to communicate with their children.

Some librarians might anticipate that serving a marginalized group risks alienating the majority users, however, this research suggests that the opposite is true: that service to one marginalized group does not happen at the expense of the majority, but rather benefits all library users. Librarians reported that story times with an ASL focus were attended not only by 
D/HoH children. Children who were pre-verbal, nonverbal, autistic, or had no disabilities benefited from story times designed for $\mathrm{D} / \mathrm{HoH}$ children. The same mainstream attendance and positive outcomes could be expected any time librarians offer programming created for underserved populations.

\section{Building Social Connections}

A major finding in this research is that by providing services for $\mathrm{D} / \mathrm{HoH}$ patrons at their libraries, librarians were able to help foster a sense of $\mathrm{D} / \mathrm{HoH}$ community and engage $\mathrm{D} / \mathrm{HoH}$ patrons with the library as a social space. For example, Librarian 9 summarized, "it's really not just their literacy, but it's building their social network." Librarian 4 echoed, "we want these children-all children-to be able to interact with each other and learn from this experience."

The interaction between majority and minority cultures that can happen as part of library programming contributes to a wider sense of community. As Librarian 4 commented,

We are very active in seeking [D/HoH people] out because [...] we want to make this a first thought for people; that this is a place for lifelong learning and no matter what your needs are we should be able to accommodate them.

In turn, Librarian 9 explained that "the reason [the library] wanted deaf signers is because then children and families are seeing real deaf people doing something for the community."

$\mathrm{D} / \mathrm{HoH}$ individuals are not the only ones with whom libraries can facilitate community building and engagement. Many patrons may fall into isolated and marginalized groups, such as nonnative English speakers, adults learning to read, immigrants, and individuals recently diagnosed with a condition or illness. By offering culturally sensitive programming based on common languages, shared experiences, or new skills sought, libraries can truly contribute to developing community connections and building bridges.

\section{Limitations}

The grounded theory design lent some weaknesses and challenges to this research. Due to the minority status of the $\mathrm{D} / \mathrm{HoH}$ population and the self-selection of interview participants, gathering sufficient data proved challenging. Participant mix and lack of prior research are two well-known limitations of grounded theory study and this research reflects those same limitations (Charmaz, 2006).

The World Health Organization (2018) defines disabling deafness in children as "hearing loss greater than $30 \mathrm{~dB}$ in the better hearing ear" (para. 2). Within the library setting, librarians have no way of knowing a child's official level of deafness. This study assumed a child to be $\mathrm{D} / \mathrm{HoH}$ if the child's parent reported the child as $\mathrm{D} / \mathrm{HoH}$ or if the child communicated with ASL. Librarians in this research did not have clinical information about a child's level of deafness or about whether the child had cochlear implants or other assistive technologies. During the interviews, librarians explained that they determined a child to be $\mathrm{D} / \mathrm{HoH}$ by seeing cochlear implants, by seeing the child use ASL or gesturing to communicate, or by report of a parent or caregiver. Librarians varied greatly in their experience communicating with $\mathrm{D} / \mathrm{HoH}$ children. Some librarians knew ASL while others used interpreters, relied on parents, or used written communication or gesturing. 
The initial contact for this research was a survey which focused on medium to large libraries based on an assumption that larger libraries with bigger service populations had more experience with $\mathrm{D} / \mathrm{HoH}$ children. A larger library also means a larger library staff, which can result in more specialization and a greater variety of experiences and backgrounds. Omitting small-sized libraries in the survey sample may have skewed the findings. The interviews did include public librarians from areas with large $\mathrm{D} / \mathrm{HoH}$ populations, where $\mathrm{D} / \mathrm{HoH}$ children live around other $\mathrm{D} / \mathrm{HoH}$ individuals and may have $\mathrm{D} / \mathrm{HoH}$ parents. This is not a typical $\mathrm{D} / \mathrm{HoH}$ experience because $\mathrm{D} / \mathrm{HoH}$ children born to hearing parents make up $96 \%$ of the $\mathrm{D} / \mathrm{HoH}$ child population (Humphries et al., 2012). D/HoH children of $\mathrm{D} / \mathrm{HoH}$ parents who use ASL do not have the same difficulties as $\mathrm{D} / \mathrm{HoH}$ children of hearing parents, especially with regard to language development and delays.

Librarians were interviewed based on their willingness to volunteer as participants. It is likely that those librarians who self-selected to be interviewed did so because they had more positive experiences to share about creating and maintaining library services for $\mathrm{D} / \mathrm{HoH}$ children. Therefore, this research may report a greater number of positive experiences in creating and implementing library services for $\mathrm{D} / \mathrm{HoH}$ children than is representative of the population of librarians as a whole.

Finally, the lack of systematic collection of data describing the demographic information of participating librarians, such as age, gender, and the number of years of experience, could be seen as a methodological omission. Although this data surfaced spontaneously in the course of the interviews, more systematically collected demographic information in subsequent studies could introduce fineness into the data.

\section{Conclusion}

The Model of Successful Library Services for D/HoH Children offers lessons that librarians can use to serve not only $\mathrm{D} / \mathrm{HoH}$ individuals, but also members of any group of diverse patrons. Being warm and welcoming, not focusing on disability, employing a diverse staff, encouraging staff to take the initiative, utilizing staff passions, partnering with nearby agencies, providing inclusive programming, including the target audience in planning, embracing minority culture, and working to build community are all effective strategies that can be employed beyond the $\mathrm{D} / \mathrm{HoH}$ population. Applying the strategies from this research would likely result in greater programming successes for any population served at a library.

Librarians who want to offer new programming can begin by looking to their staff and community. If there are nearby agencies that serve a particular community, then collaborating with those agencies is an important first step. As this research illustrates, nearby agencies can help with more than patron referral; they can also help with recruiting volunteers, staff training, promotional opportunities, and other endeavors. Library staff can assist in making these crucial connections by utilizing their own passions, skills, and networks. Employing a diverse staff is another factor that helps to attract underserved populations.

It is important for librarians to recognize that staff attitude is crucial in serving minority populations like $\mathrm{D} / \mathrm{HoH}$ patrons. In this research, librarians were warm and welcoming, took the initiative to serve $\mathrm{D} / \mathrm{HoH}$ children, and did not perceive $\mathrm{D} / \mathrm{HoH}$ children as disabled. These values laid the framework for successfully serving $\mathrm{D} / \mathrm{HOH}$ children at their libraries. For practicing librarians, this means that one of the most impactful factors in providing successful programming is attitude and behavior, which is within the power of each librarian to control

The International Journal of Information, Diversity, \& Inclusion, 2(3), 2018

ISSN 2574-3430, publish.lib.umd.edu/IJIDI/ 
and is not contingent upon budget or other library limitations.

In this study, librarians reported that a significant outcome of their $\mathrm{D} / \mathrm{HoH}$ programming was building communities for marginalized groups, both for $\mathrm{D} / \mathrm{HoH}$ populations and hearing populations. Librarians relied on $\mathrm{D} / \mathrm{HoH}$ individuals to help plan programming, lead book discussions, volunteer, and recruit program attendees. The importance of relying on community members who represent the served population was also highlighted. These community members may be staff, regular patrons, representatives from a nearby agency, or community gatekeepers.

Because the recognition of diverse populations is more prevalent than ever, it is critical that librarians continuously question the existing models and ask such tough questions as: "Does this model apply to everyone?" and "Who might this practice or policy exclude?" Once librarians have identified obstacles to service for particular groups, they can begin planning their activities differently. There is a need for increasing public awareness of the free and highquality services that librarians create for $\mathrm{D} / \mathrm{HoH}$ children and their families; awareness is also needed of the fact that such services are not available in every location or library. In sum, this study, and the Model of Successful Library Services for D/HoH Children drawn from it, can offer valuable lessons to librarians who seek out opportunities to serve the underserved populations.

\section{Acknowledgements}

Thank you to Dr. Keren Dali and IJIDI reviewers. Your patient editorial assistance made this paper possible.

\section{Appendix A}

\section{Recruitment Script}

Dear Librarian,

I am conducting a survey about library services for deaf children in public libraries. This online survey should take 10-30 minutes, depending on how much information you have to share. You may refuse to answer any question, and you may leave the survey at any time by closing your browser window.

My goal with this survey is to collect information and best practices for conducting library services for deaf children. I hope this project will benefit the library community by helping other libraries to develop library services that are accessible to deaf children, and to learn what situations other libraries have faced in offering these services.

Will you protect my privacy? Yes. This survey is set up so no information about you or your IP address is collected. I will store survey data without personal information for three years prior to destroying it, but the data will be stored on a password-protected server. I will not collect or release any identifying information. 
Why am I getting this? Your library was chosen from a listing of all U.S. libraries with a service population of over 100,000 people. I chose libraries with over 100,000 people to maximize the possibility of your having interacted with deaf children in your service area. I also thought that larger libraries were more likely to have the budget and personnel to respond to the needs of deaf children.

If you prefer not to be contacted or not to participate, please reply to this email and we will take you off our mailing list.

Whom can you contact for more information? If you have questions about the research, please contact the investigator, Bobbie Bushman, at bobbiebushman@gmail.com. If you have questions about your rights as a research participant, please contact the University of Missouri Institutional Review Board at 573-882-9585 or irb@missouri.edu.

By clicking "yes" below, you are indicating that you have read the information above and choose to participate in this research.

Thank you very much for your attention.

Bobbie Bushman (Librarian/Doctoral Student)

University of Missouri School of Information Science \& Learning Technologies

\section{Appendix B}

\section{Questionnaire}

This online survey is about library services for deaf children in public libraries and should take 10-30 minutes, depending on how much information you have to share. You may refuse to answer any question, and you may leave the survey at any time by closing your browser window.

\section{Library Planning and Evaluation}

Has your library conducted a community analysis or other formal study to identify deaf children in your service area?

- YES

- NO

- I don't know

Does your library have plans to include services to deaf individuals (either children or adults)?

- YES

- NO

The International Journal of Information, Diversity, \& Inclusion, 2(3), 2018 ISSN 2574-3430, publish.lib.umd.edu/IJIDI/ 
- Our library mission includes a statement about services to people with disabilities, but not specifically deaf

Have you or other library employees attended in-service or off-site training about working with special needs children?

- YES

- NO

If YES, who provided those services?

- Community agency

- Consultant

- College instructor/class

- Other

- Library Association

\section{Your Child Patrons}

Does your library have deaf children in its service area?

- NO

- YES

- I don't know

If YES, have you or other library staff interacted with those deaf children?

- NO

- YES

\section{Library Programming}

Does your library provide programming for children?

- NO

- YES

If YES, please select all that apply.

- Story time

- Summer Reading Program

The International Journal of Information, Diversity, \& Inclusion, 2(3), 2018 ISSN 2574-3430, publish.lib.umd.edu/IJIDI/ 
- Family programs

- Craft programs

- Puppet shows

- Storytelling

- Other (please specify)

Does your library provide separate programming for deaf children?

- YES

- NO

If you provide programming (separate or inclusive) for deaf children, how was that service initiated?

- Children's/Youth Department on our own initiative

- Request by administrators

- Request by teachers

- Request by parents/caregivers

- $\quad$ Other (Please specify)

- I don't know

\section{Resources}

Are there resources in your community to help serve deaf children? Examples might be special schools, health departments, etc.

- YES

- NO

- I don't know

If Yes, please specify.

\section{Equipment}

Do you provide specialized accommodations to deaf children? If so, please indicate the equipment below.

- $\quad$ ASL staff or interpreter

- $\quad$ Books with ASL pictures

The International Journal of Information, Diversity, \& Inclusion, 2(3), 2018 ISSN 2574-3430, publish.lib.umd.edu/IJIDI/ 
- TTY communicator

- $\quad$ Computers with assistive software

- $\quad$ Videos with ASL

Other (please specify)

\section{Challenges}

What are some of the challenges your library faces in providing services to deaf children?

- Not enough resources (money/time)

- Staff need more education/training

- Not a priority

- Uninterested/Non-participating patrons

- Uninterested/Non-participating/Untrained library staff

- Uninterested/Non-participating library administrators

- Communication barriers

- $\quad$ Other (please specify)

\section{Follow-Up to Survey}

Would you be willing to participate in a telephone interview about your library's provisions for special needs children?

YES/NO

If Yes, please provide your contact information.

\section{Appendix C}

\section{Semi-structured Interview Script and Questions}

Hello. This is Bobbie Bushman from the University of Missouri. I recently sent an email about interviewing you. I am interested to know more about your early literacy experiences working with deaf children.

Since you indicated that you were willing to be interviewed, I want to begin with a few general questions about your experience. Feel free to interrupt or elaborate at any point. Also, we should let you know that you can feel free to stop this interview at any time or choose not to answer any question. You can also feel free to ask us questions, too. I anticipate that this 
interview will take about 30 minutes.

1. Describe the deaf population at your library.

2. How did you begin serving this deaf population?

3. How did you decide what programming to provide for deaf children?

4. Is your programming "mainstreamed"? That is, do all children participate in programming regardless of hearing ability? Or is it specific to only deaf children?

5. Can you tell me about your experience serving deaf adults? How does this relate to library services to deaf children?

6. Describe the implementation of your deaf programming.

7. Tell me about the training you have related to deaf literacy.

8. Does your library use Every Children Ready to Read or a similar "reading readiness" program? If so, which one? Where can I get a copy or more information about the reading readiness program your library uses?

9. How well do you find that this "reading readiness" program applies to deaf children?

10. Tell me about a program for a deaf child at your library that was a great success.

11. Tell me about a time when you tried to provide a library program for deaf children and encountered difficulties or failure.

12. Have you partnered with any other facilities, early educators, schools, libraries, etc. in order to serve deaf children?

13. Is there anything else you would like to add? Do you have feedback about things I should have asked or should not ask?

I don't have any more questions for you. I would like to thank you for talking to me so candidly. If you have any further questions, please feel free to be in touch.

\section{Appendix D}

\section{Coding Example}

This is an example of first phase coding from one of the longer, more descriptive interviews. To protect the participants' privacy, identifying information has been replaced with ${ }^{* * * *}$. 


\begin{tabular}{|c|c|}
\hline In Vivo Codes & Open, First Cycle Codes \\
\hline $\begin{array}{l}\text { We have a really diverse deaf population. } \\
\text { We work with deaf/blind, low vision, } \\
\text { deaf, blind, deaf, and then hard of } \\
\text { hearing individuals who come in to use } \\
\text { library services. Now this is a mix of } \\
\text { children and adults. }\end{array}$ & POPULATION? \\
\hline $\begin{array}{l}\text { [We work] with the Deaf Services } \\
\text { Coordinator with trying to get grants and } \\
\text { TTYs or interpreters. At the library, we } \\
\text { have a long history of working with our } \\
\text { deaf population in the area. So, over the } \\
\text { years we've worked with various agencies } \\
\text { [like the] deaf theater groups, student } \\
\text { groups, and other agencies, state } \\
\text { agencies who support deaf services and } \\
\text { community programs. }\end{array}$ & $\begin{array}{l}\text { IMPETUS } \\
\text { SUPPORT/PARTNERSHIPS }\end{array}$ \\
\hline $\begin{array}{l}\text { We have ... programs for early learning } \\
\text { and the library has partnered with this } \\
\text { [deaf] group in order to provide story } \\
\text { time activities here at the library and } \\
\text { we'll also go to that agency. }\end{array}$ & SUPPORT/PARTNERSHIPS \\
\hline $\begin{array}{l}\text { We have a junior high school with deaf } \\
\text { services programs called } * * * * * \text { Middle } \\
\text { School and we have a high school. The } \\
\text { high school has [a] deaf services program } \\
\text { for young people. And we have another } \\
\text { high school outside of the area, an } \\
\text { elementary school that works with deaf } \\
\text { children. }\end{array}$ & SUPPORT/PARTNERSHIPS \\
\hline $\begin{array}{l}\text { [Our } \mathrm{D} / \mathrm{HoH} \text { programming is] a result of } \\
\text { the deaf community advocating. [It is] } \\
\text { really wonderful about [them] being in } \\
\text { touch with us, letting us know when they } \\
\text { need to use our space, and [when they] } \\
\text { have questions. }\end{array}$ & IMPETUS \\
\hline
\end{tabular}

The International Journal of Information, Diversity, \& Inclusion, 2(3), 2018 ISSN 2574-3430, publish.lib.umd.edu/IJIDI/ 


\begin{tabular}{|c|c|}
\hline In Vivo Codes & Open, First Cycle Codes \\
\hline $\begin{array}{l}\text { We actually had a deaf individual who } \\
\text { wrote the grant, who assisted us as a } \\
\text { volunteer, and then later went on to work } \\
\text { with us to get the TTYs early on. }\end{array}$ & SUPPORT/PARTNERSHIPS \\
\hline $\begin{array}{l}\text { We have an American Sign Language story } \\
\text { time that's offered at our branch libraries } \\
\text { that has a mix of deaf and hearing } \\
\text { children attending. }\end{array}$ & SERVICES/PROGRAMS \\
\hline $\begin{array}{l}\text { We will also provide interpreters for deaf } \\
\text { children and families to attend any } \\
\text { program. }\end{array}$ & $\begin{array}{l}\text { SERVICES/PROGRAMS } \\
\text { MODIFICATIONS/ACCOMMODATIONS }\end{array}$ \\
\hline $\begin{array}{l}\text { So, we have a lot of DVDs related to sign } \\
\text { language. We have books about, "My } \\
\text { friend is deaf," those kind of } \\
\text { informational materials. }\end{array}$ & $\begin{array}{l}\text { SERVICES/PROGRAMS } \\
\text { MODIFICATIONS/ACCOMMODATIONS }\end{array}$ \\
\hline $\begin{array}{l}\text { The program that I work with is called } \\
* * * * * \text { and I am a librarian but in charge } \\
\text { with coordinating services for deaf, } \\
\text { special needs, [and] blind individuals. }\end{array}$ & SERVICES/PROGRAMS \\
\hline $\begin{array}{l}\text { We have an ASL book group and that } \\
\text { focuses on deaf adults. }\end{array}$ & SERVICES/PROGRAMS \\
\hline $\begin{array}{l}\text { We just had a huge program that } \\
\text { addressed domestic violence in the deaf } \\
\text { community. That was sponsored by an } \\
\text { abused deaf women's advocacy group. }\end{array}$ & $\begin{array}{l}\text { SERVICES/PROGRAMS } \\
\text { SUPPORT/PARTNERSHIPS }\end{array}$ \\
\hline We've had [deaf] films. & SERVICES/PROGRAMS \\
\hline $\begin{array}{l}\text { [We work with] }{ }^{* * * *} \text { Deaf }{ }^{* * * * * *} \text { Advocacy } \\
\text { Center. And we've done a number of } \\
\text { programs with them over the years. }\end{array}$ & SUPPORT/PARTNERSHIPS \\
\hline
\end{tabular}

The International Journal of Information, Diversity, \& Inclusion, 2(3), 2018 ISSN 2574-3430, publish.lib.umd.edu/IJIDI/ 


\begin{tabular}{|c|c|}
\hline In Vivo Codes & Open, First Cycle Codes \\
\hline Our focus program is the ASL story time. & SERVICES/PROGRAMS \\
\hline We always have [a deaf] storyteller. & MODIFICATIONS/ACCOMMODATIONS \\
\hline $\begin{array}{l}\text { What we focus on is language learning. } \\
\text { So, we'll focus on basic ASL, ABCs-the } \\
\text { alphabet and we use books that are very } \\
\text { colorful, engaging, and we'll have an } \\
\text { interpreter who will voice the } \\
\text { information. We explain to the children } \\
\text { that although-and it could be a male } \\
\text { voice or a female voice-and although } \\
\text { there's a voice that you hear, we want } \\
\text { you to focus on the individual who is } \\
\text { signing because they're communicating. }\end{array}$ & $\begin{array}{l}\text { MODIFICATIONS/ACCOMMODATIONS } \\
\text { SERVICES/PROGRAMS }\end{array}$ \\
\hline $\begin{array}{l}\text { Through our ASL programs, we try to } \\
\text { educate children about deafness and for } \\
\text { deaf children we want them to be } \\
\text { engaged and have someone who speaks } \\
\text { directly to them. And it's so interesting to } \\
\text { watch the different populations where } \\
\text { the deaf children are just so entrenched } \\
\text { in watching the deaf storyteller. And then } \\
\text { the hearing children are very interest[ed] } \\
\text { in just the movement }\end{array}$ & OUTCOMES \\
\hline $\begin{array}{l}\text { [There is] learning that's going on. [The } \\
\text { child will say,] "Mommy, he's talking but } \\
\text { she's signing." and [the result of that } \\
\text { realization is a] comfort with } \\
\text { understanding deafness. }\end{array}$ & OUTCOMES \\
\hline $\begin{array}{l}\text { We go to the [deaf center] and its target } \\
\text { educating children so it's your ABCs, it's } \\
\text { some of your-it's understanding fruits } \\
\text { and different subjects and it's very } \\
\text { similar, it's similar-it IS exactly the same } \\
\text { as our story times for young people who } \\
\text { are learning, who are hearing children. }\end{array}$ & SUPPORT/PARTNERSHIPS \\
\hline
\end{tabular}

The International Journal of Information, Diversity, \& Inclusion, 2(3), 2018 ISSN 2574-3430, publish.lib.umd.edu/IJIDI/ 


\begin{tabular}{|c|c|}
\hline In Vivo Codes & Open, First Cycle Codes \\
\hline $\begin{array}{l}\text { We're focusing on books and learning, and } \\
\text { learning about different subjects. It could } \\
\text { be, "What do you need when you're going } \\
\text { on a vacation?" Or, "What do you need if } \\
\text { you're going to school," and "How do you } \\
\text { prepare?" So, and it's just with the } \\
\text { overlay of the interpreter and educating } \\
\text { about sign language. }\end{array}$ & MODIFICATIONS/ACCOMMODATIONS \\
\hline $\begin{array}{l}\text { We have a large deaf community in the } \\
\text { area so they're involved with deaf } \\
\text { spotlight [celebrating achievements of } \\
\text { deaf individuals] and/or they are ASL } \\
\text { instructors who are involved with drama } \\
\text { and teaching. }\end{array}$ & SUPPORT/PARTNERSHIPS \\
\hline $\begin{array}{l}\text { We advertise through the deaf community } \\
\text { so we'll ask, like, Hearing, Speech and } \\
\text { Deafness Center, "Do you know of deaf } \\
\text { artists?" We'll go through our community } \\
\text { college, "Do you know of deaf artists?" } \\
\text { And we have a really strong deaf } \\
\text { community over the years so it hasn't } \\
\text { been difficult to find people. }\end{array}$ & SUPPORT/PARTNERSHIPS \\
\hline Our ASL storytellers are ASL instructors. & SUPPORT/PARTNERSHIPS \\
\hline $\begin{array}{l}\text { We just have the deaf storyteller and the } \\
\text { interpreter so we have an easel so it will } \\
\text { make it easy for the deaf storyteller to } \\
\text { turn the page. We will sometimes do a } \\
\text { projection. So, the book is on the screen } \\
\text { and they just have to hit the clicker to go } \\
\text { to the next page. }\end{array}$ & MODIFICATIONS/ACCOMMODATIONS \\
\hline
\end{tabular}

The International Journal of Information, Diversity, \& Inclusion, 2(3), 2018 ISSN 2574-3430, publish.lib.umd.edu/IJIDI/ 


\begin{tabular}{|c|c|}
\hline In Vivo Codes & Open, First Cycle Codes \\
\hline $\begin{array}{l}\text { We would have two interpreters for the } \\
\text { deaf/blind individual. And then one- } \\
\text { maybe, it could, in most cases it's } \\
\text { another deaf individual who's doing the } \\
\text { copy signing. And so, we may have three } \\
\text { or four interpreters. }\end{array}$ & MODIFICATIONS/ACCOMMODATIONS \\
\hline $\begin{array}{l}\text { We offer story time in different languages } \\
\text { [Somali, Spanish]. And so, having an ASL } \\
\text { story time was just a natural offshoot. }\end{array}$ & $\begin{array}{l}\text { SERVICES/PROGRAMS } \\
\text { IMPETUS }\end{array}$ \\
\hline $\begin{array}{l}\text { We have a Spanish [and Russian] language } \\
\text { book group. And so, the ASL was an } \\
\text { offshoot. }\end{array}$ & $\begin{array}{l}\text { SERVICES/PROGRAMS } \\
\text { IMPETUS }\end{array}$ \\
\hline $\begin{array}{l}\text { We do rely on the deaf community to let } \\
\text { us know what is interesting. }\end{array}$ & SUPPORT/PARTNERSHIPS \\
\hline $\begin{array}{l}\text { We had deaf nee-kay where there was a } \\
\text { deaf Chinese individual involved with the } \\
\text { internment camps. }\end{array}$ & SERVICES/PROGRAMS \\
\hline $\begin{array}{l}\text { We just happened to be having a big } \\
\text { library conference in the area and so we } \\
\text { were able to highlight a video related to } \\
\text { how the deaf community and the librarian } \\
\text { community could come together and learn } \\
\text { about deaf history. }\end{array}$ & TRAINING \\
\hline $\begin{array}{l}\text { If we have a child who's deaf and needs } \\
\text { support in a program, that's where we } \\
\text { hire the interpreters. }\end{array}$ & MODIFICATIONS/ACCOMMODATIONS \\
\hline
\end{tabular}




\begin{tabular}{|c|c|}
\hline In Vivo Codes & Open, First Cycle Codes \\
\hline $\begin{array}{l}\text { [We got] referrals from the deaf center. } \\
\text { We work with the Deaf/Blind Services } \\
\text { Center. We work with Helen Keller Center } \\
\text { for Deaf/Blind. We work with the } \\
\text { Lighthouse for the Blind that has } \\
\text { deaf/blind employees. We-gosh, work } \\
\text { with the office of deaf and hard of } \\
\text { hearing that's in our state capitol. }\end{array}$ & SUPPORT/PARTNERSHIPS \\
\hline $\begin{array}{l}\text { We had a video phone and video phone } \\
\text { resources early on. }\end{array}$ & SERVICES/PROGRAMS \\
\hline $\begin{array}{l}\text { We worked with our community colleges } \\
\text { for ASL students who are studying who } \\
\text { may need library resources or who need } \\
\text { to attend programs related to the deaf } \\
\text { community. }\end{array}$ & $\begin{array}{l}\text { SUPPORT/PARTNERSHIPS } \\
\text { SERVICES }\end{array}$ \\
\hline $\begin{array}{l}\text { They have a summer program for } \\
\text { deaf/blind individuals. }\end{array}$ & SUPPORT/PARTNERSHIPS \\
\hline $\begin{array}{l}\text { We virtually work with a number of } \\
\text { agencies in the area-we work with the } \\
\text { Association for the Deaf. }\end{array}$ & SUPPORT/PARTNERSHIPS \\
\hline
\end{tabular}




\begin{tabular}{|c|c|}
\hline In Vivo Codes & Open, First Cycle Codes \\
\hline $\begin{array}{l}\text { As soon as you sign 'a', you turn around } \\
\text { and so instead of having to say 'a', you } \\
\text { sign 'a' and then turn around. And the } \\
\text { hearing children-you know, everybody is } \\
\text { doing that. And so, "let's sign 'a'" and so } \\
\text { dance and make a circle. So, "The Wheels } \\
\text { on the Bus" it's kind of a little larger than } \\
\text { life and it's easy signs and like, "wheels" } \\
\text { and then "bus" so all of the children can } \\
\text { participate and that's really important } \\
\text { whereas-and they're easy songs that we } \\
\text { can sign that deaf children don't need to } \\
\text { necessarily hear or know the words. } \\
\text { They're familiar with it. What is it? Itsy } \\
\text { Bitsy Spider because those are fun signs. } \\
\text { l'm trying to think of songs. Let's see, } \\
\text { "We All Get Together," and so the deaf } \\
\text { children-and we know- and the deaf } \\
\text { signer will sign, you know, "This is a song } \\
\text { and you sign and you can voice," or "let's } \\
\text { all sign together." }\end{array}$ & MODIFICATIONS/ACCOMMODATIONS \\
\hline Differences are celebrated. & STAFF ATTITUDES/EXPERIENCES \\
\hline $\begin{array}{l}\text { We try to separate out the communities } \\
\text { so it's not seen as "disabled" and express } \\
\text { it with the deaf community. It's } \\
\text { communication, which isn't a disability. }\end{array}$ & STAFF ATTITUDES/EXPERIENCES \\
\hline
\end{tabular}

\section{References}

Adkins, D., \& Bushman, B. (2015). A special needs approach. Children \& Libraries, 13(3), 28-33.

American Library Association (ALA). Every child ready to read (ECRR). (n.d.). Retrieved from http: //www.everychildreadytoread.org/

ALA Office for Research \& Statistics. (2017). 2017 ALA demographic study. Retrieved from http://www.ala.org/research/initiatives/membershipsurveys

Arnold, M. (2002). Adapting library services at the Colorado School for the Deaf and Blind -orspecial collections for special kids. Colorado Libraries, 28(4), 25-27. 
Banks, C. (2004). All kinds of flowers grow here: The children's place for children with special needs at Brooklyn Public Library. Children and Libraries, 2(1), 5-10.

Birks, M., \& Mills, J. (2011). Grounded theory: A practical guide. Thousand Oaks, CA: SAGE Publications.

Blue, E. V., \& Pace, D. (2011). UD and UDL: Paving the way toward inclusion and independence in the school library. Knowledge Quest, 39(3), 48-55.

Bryant, A., \& Charmaz, K. (Eds.). (2007). The SAGE handbook of grounded theory. Thousand Oaks, CA: SAGE Publications.

Charmaz, K. (2006). Constructing grounded theory: A practical guide through qualitative analysis. Thousand Oaks, CA: SAGE Publications.

Corbin, J. M., \& Strauss, A. L. (2008). Basics of qualitative research: Techniques and procedures for developing grounded theory (3rd ed.). Thousand Oaks, CA: SAGE Publications.

Creswell, J. W. (2008). Educational research: Planning, conducting, and evaluating quantitative and qualitative research ( $3^{\text {rd }}$ ed.). Upper Saddle River, NJ: Person Education.

Creswell, J. W. (2009). Research design: Qualitative, quantitative, and mixed methods approaches. Thousand Oaks, CA: SAGE Publications.

Davis, D. M., \& Hall, T. D. (2007). Diversity counts. Office for Research and Statistics. Office for Diversity. Retrieved from

http://www.ala.org/aboutala/sites/ala.org.aboutala/files/content/diversity/diversity counts/diversitycounts_rev0.pdf

Hands, A. S., \& Johnson, A. (2012). Lighting the way: Grant applications showcase range of programming ideas. Children and Libraries, 10(2), 56-57.

Hastings, S. K. (2015). If diversity is a natural state, why don't our libraries mirror the populations they serve? The Library Quarterly: Information, Community, Policy, 85(2), 133-138.

Humphries, T., Kushalnagar, P., Mathur, G., Napoli, D. J., Padden, C., Rathmann, C., \& Smith, S. R. (2012). Language acquisition for deaf children: Reducing the harms of zero tolerance to the use of alternative approaches. Harm Reduction Journal, 9, 1-9.

Institute of Museum and Library Services (IMLS). (2010). Public libraries survey (PLS) data and reports. Retrieved from https://www.imls.gov/research-evaluation/datacollection/public-libraries-survey/explore-pls-data/pls-data

Jaeger, P., Bertot, J. C., \& Subramaniam, M. (2013). Preparing future librarians to effectively serve their communities. The Library Quarterly: Information, Community, Policy, 83(3), 243-248.

Kumbier, A., \& Starkey, J. (2016). Access is not problem solving: Disability justice and 
libraries. Library Trends, 64(3), 468-491.

Lajoie, L. (2003). Embracing the silence: How librarians can help deaf children develop their reading skills. School Library Journal, 49(8), 43.

MacMillan, K. (2003). Signs of success: ASL access opens the door between deaf and hearing. Public Libraries, 42(1), 17-19.

Massis, B. (2013). Library partnerships: A key to growth. New Library World, 114(11/12), 550553.

McCaffrey, M. (2004a). Great books in sign language. School Library Journal, 50(12), 30.

McCaffrey, M. (2004b). The missing link. School Library Journal, 50(9), 48-49.

Nail, S. (2008). ASL Tales bridges the gap between deaf and hearing children. Feliciter, 54(6), 280-285.

Noland, A. (2003). How Cleveland serves the Deaf community. Public Libraries, 42(1), 20-21.

Pinellas Public Library Cooperative. (2016). Deaf Literary Center: A bridge to the world of information. Retrieved from http: //www.pplc.us/dlc/

Rodriguez, R., \& Reed, M. (2003). Our deaf family needs to read, too. Public Libraries, 42(1), 38-41.

Vander Broek, J. L., \& Rodgers, E. P. (2015). Better together: Responsive community programming at the U-M Library. Journal of Library Administration, 55(2), 131-141.

Wemett, L. C. (2007). The Building Bridges Project: Library services to youth with disabilities. Children and Libraries, 5(3), 15-20.

White, B. (2011). The world in words and pictures: How graphic novels can help to increase the reading comprehension for students with hearing loss. Knowledge Quest, 39(3), 18-25.

Wong, Y. L. (2009). Homelessness in public libraries. Journal of Access Services, 6(3), 396-410.

World Health Organization (2018, March 15). Deafness and hearing loss. Retrieved from http://www.who.int/en/news-room/fact-sheets/detail/deafness-and-hearing-loss

Bobbie Bushman (bobbie.bushman@unt.edu) is the Houston Program Coordinator and Lecturer at the University of North Texas. She teaches courses in public libraries, library literature for children and young adults, adult reader's advisory, and digital citizenship. 